\title{
The Representation between Cardi and Decumani of the Historical Center of Naples
}

\author{
Luigi Corniello
}

\begin{abstract}
The historical Center of Naples (Neapolis) presents, again, the division into four zone consist of three wide streets and parallel (the Decumani) and numerous alleys (Cardi) of smaller width, with trends straight from north to south, parallel each other and perpendicular to the three main streets. The first, the Cathedral is located overlooking the Cardo now Via Duomo, which connects the Central Decumano and the top. The second complex is the Benedictine monastery of San Lorenzo between the central and lower Cardo. It leads to Piazza San Gaetano on which also raises the Church of S. Paolo. The third complex (Jesuit) suggests the Piazza del Gesu Nuovo which is the starting central Decumano (via S. Biagio dei Librai). The fourth overall promises on Piazza del Gesù Nuovo with Renaissance church named. From the reading of the ancient center, with reference to the contemporary storyline road, you may experience some of the many architectural examples of Naples.
\end{abstract}

Keywords---Representation, Drawing, Historical Center Of Naples, UNESCO.

\section{INTRODUCTION}

The itinerary of research is focused on the analysis of the historical Center of Naples in the Neapolitan Gulf, and proposed acquisitions and reflections on the Campania Region. The area of one hundred forty six hectares, where are located the architectural structures, are elevated structures and layers dating from ancient times to our times. Naples promises to on the gulf in the form of an amphitheater on the hill slopes of Vesuvius, the Campi Flegrei and many coastal cities, with the islands of Capri, Ischia and Procida. The succession of civilizations that settled the ancient center of the Greek Roman cities, developed later construction of civil and sacred factories, public and religious character that testify to the activities and developments realized in architectural styles, pictorial and decorative style of each Roman age and again in the early Christian period until the age Gothic and Baroque. Complex recruited for the itinerary give the reader simulation to be lived on the site based on a number of concepts that are inherent to a collection of testimonies of the figurative arts. The peculiarities of each area of the city, architecture and urban development are located on the ancient road system with the materials of the area and a constructive environment that shows the building development over the centuries with a marked elevation in height and of public buildings to the private ones, the road network can be seen that original remained unchanged over the centuries. In historical reality the system of roads, a reticular character, takes place on roads with a width of around 6.00 meters, called Decumani, and the narrower streets, around 3.00 meters, known as Cardi, perpendicular to the first. In Naples the Decumani in the ancient center are three and around them we find in elevation or in underground areas testimonies Greek Roman and early Christian Age. In this architectural context it rises the residential building fabric with a height of about two floors. To have a visual reference of such structures just follow the ancient city of Pompeii (Fourth Century BC) who, following the excavations carried out in the Nineteenth Century, you have the vision of a complete city in all its parts above the ground.

The progressive growing of residential buildings from the Middle Ages to our times has created a inadequate environment in relation to hygiene, transport, human and vehicular traffic everyday. And it is in this building fabric, with numerous testimonies of art and culture that we find the Gothic and Baroque complexes between the Greek Roman and early Christian structures. The historical center of Naples (Neapolis) presents, again, the division into four zone consist of three wide streets and parallel (the Decumani) and numerous alleys (the Cardi) of smaller width, with trends straight from north to south, parallel each other and perpendicular to the three main streets: the lower Decumani, the middle and upper Decumani from east to west. In this environment, with the hilly course, are located the complex engaged in symbolic places, historic route of the architectural, the urban and the landscape. The first, the Cathedral (the Duomo) is located overlooking the Cardo now Via Duomo, which connects the Central Decumano and the top. The second complex is the Benedictine Monastery of San Lorenzo between the central and lower Cardo. It leads to Piazza San Gaetano on which also raises the Church of S. Paolo.

The third complex (Jesuit) suggests the Piazza del Gesu Nuovo which is the starting central Decumano (via S. Biagio dei Librai). The fourth overall promises on Piazza del Gesù Nuovo with Renaissance church named. From the reading of the ancient center, with reference to the contemporary storyline road, you may experience some of the many architectural examples of Naples. Among the lower and middle Decumani they notice masonry traces of the market and of the baths, between the central and the top of the theater traces the remains of which are visible for the circular geometry of homes that have been built over the centuries. 


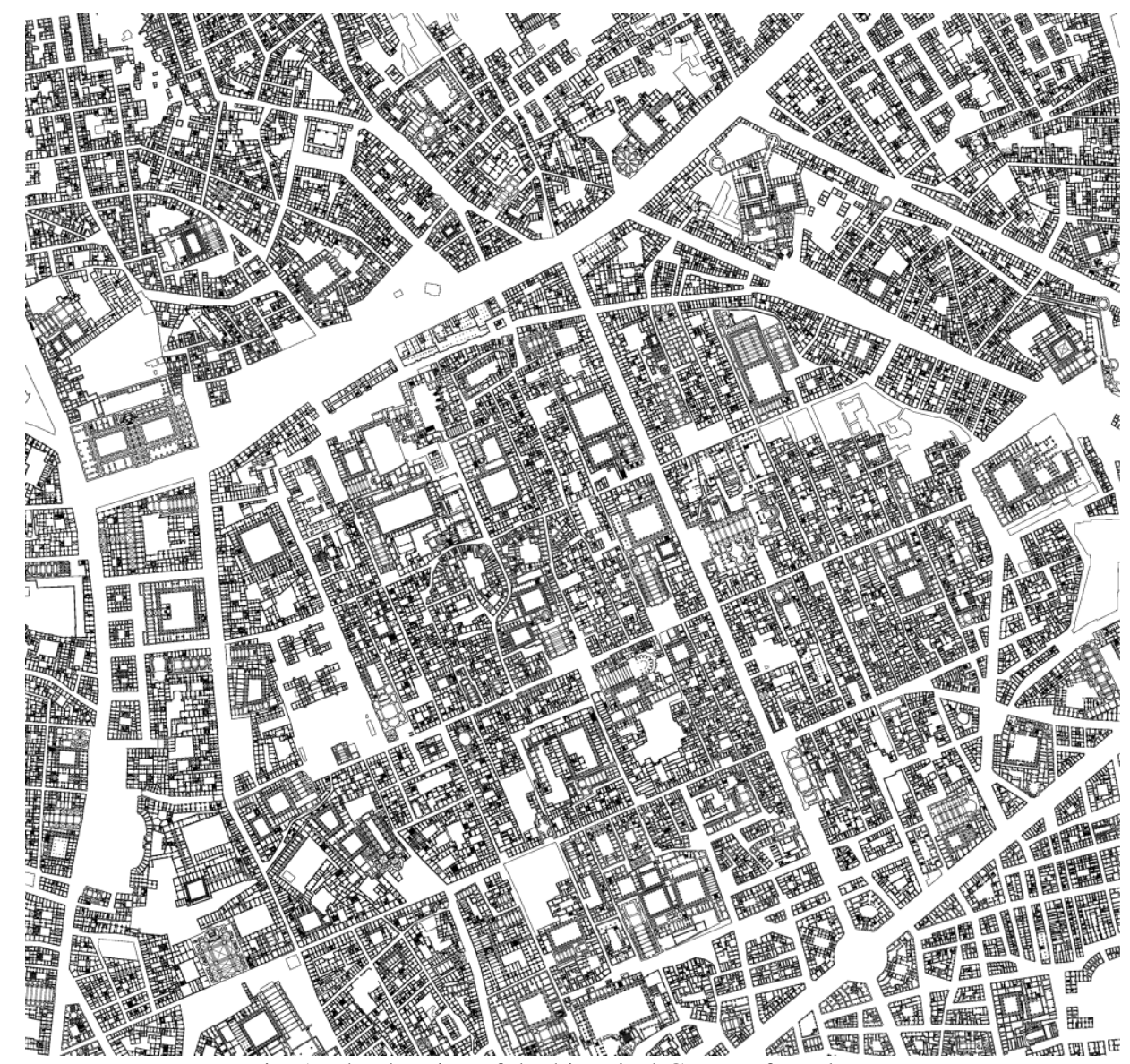

Fig. 1: The drawing of the historical Center of Naples.

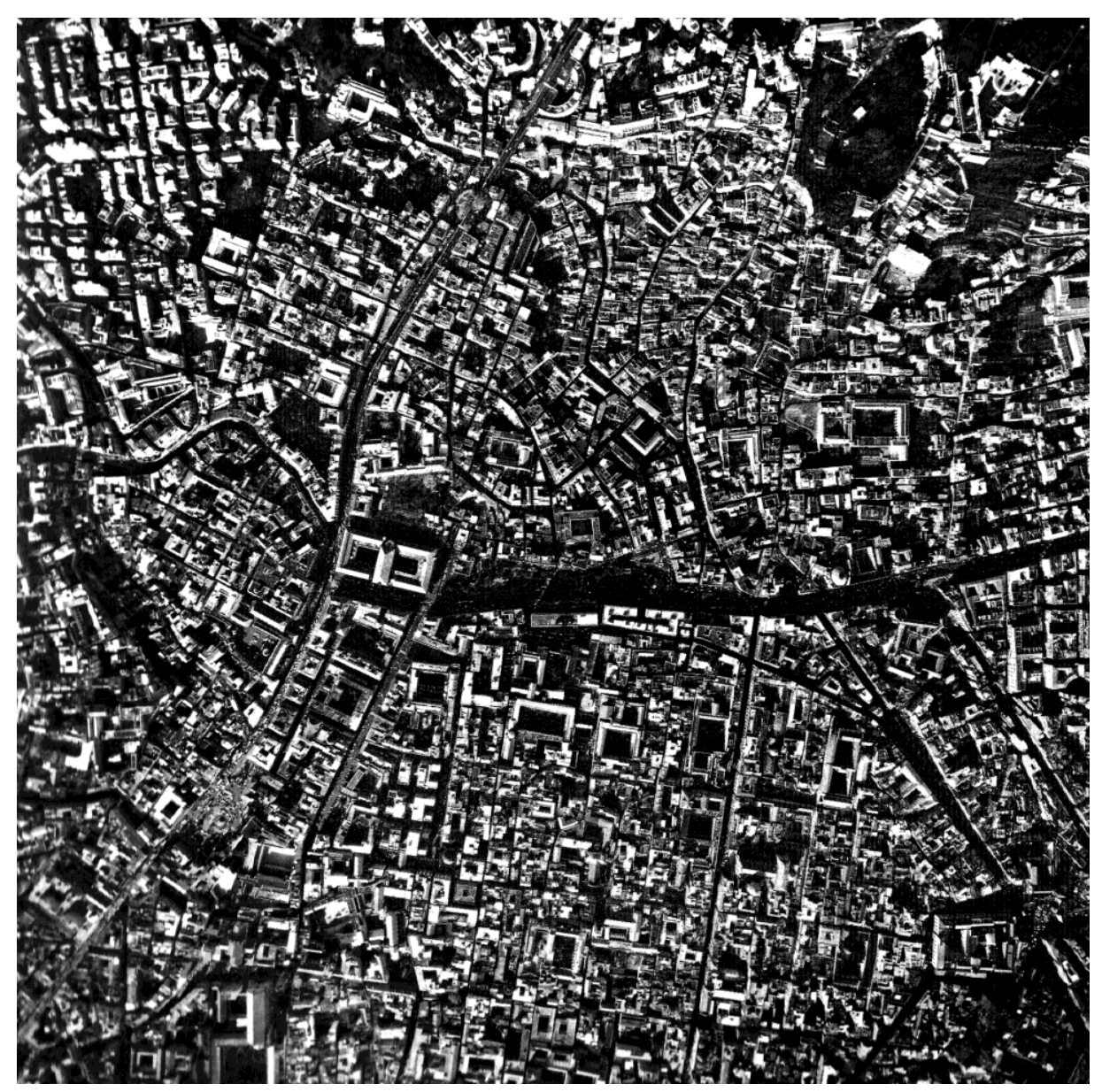

Fig. 2: The orthophoto of the historical Center of Naples. 


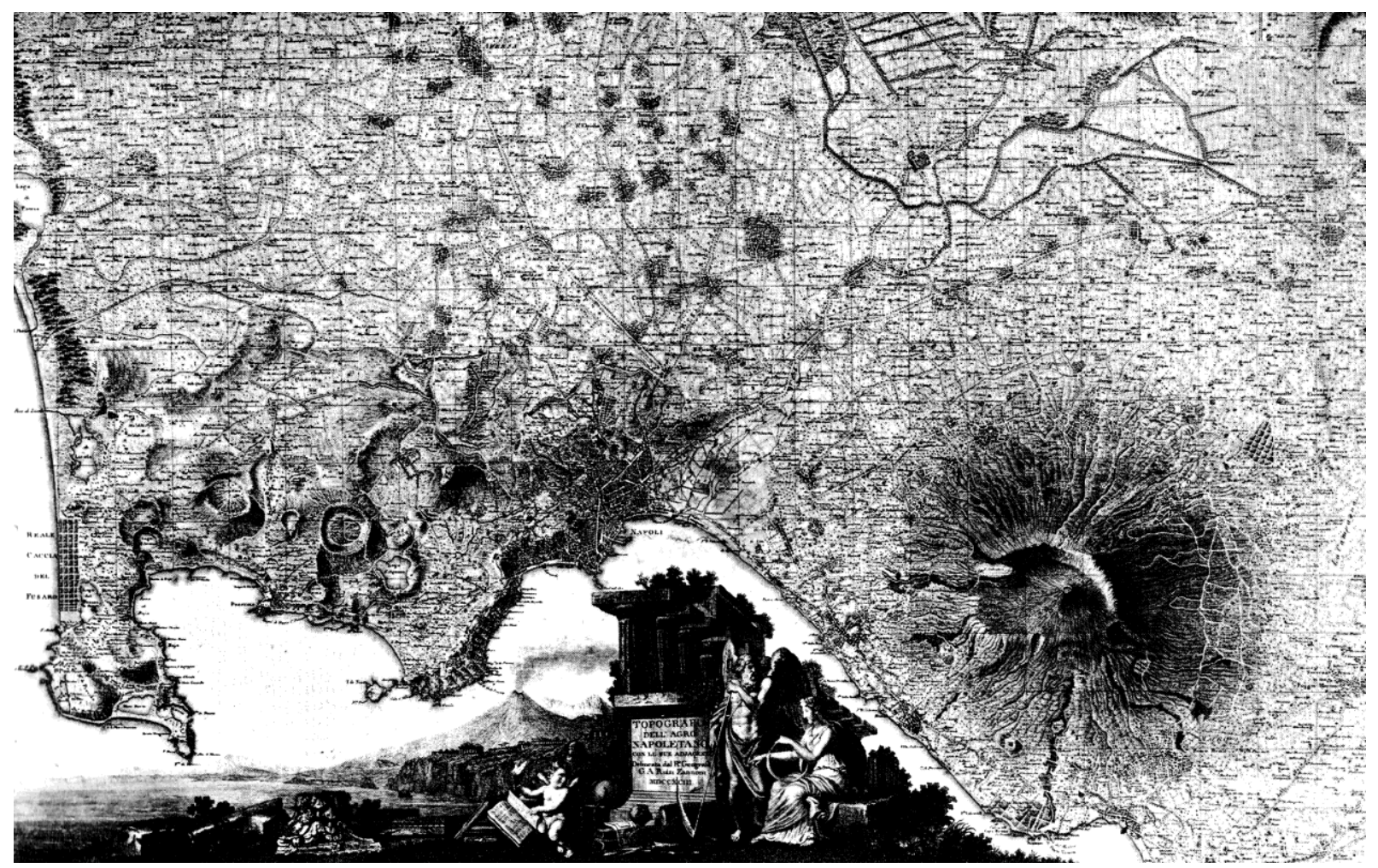

Fig. 3: G. A. Rizzi-Zannoni, topography Agro Napoletano with its surroundings (1793).

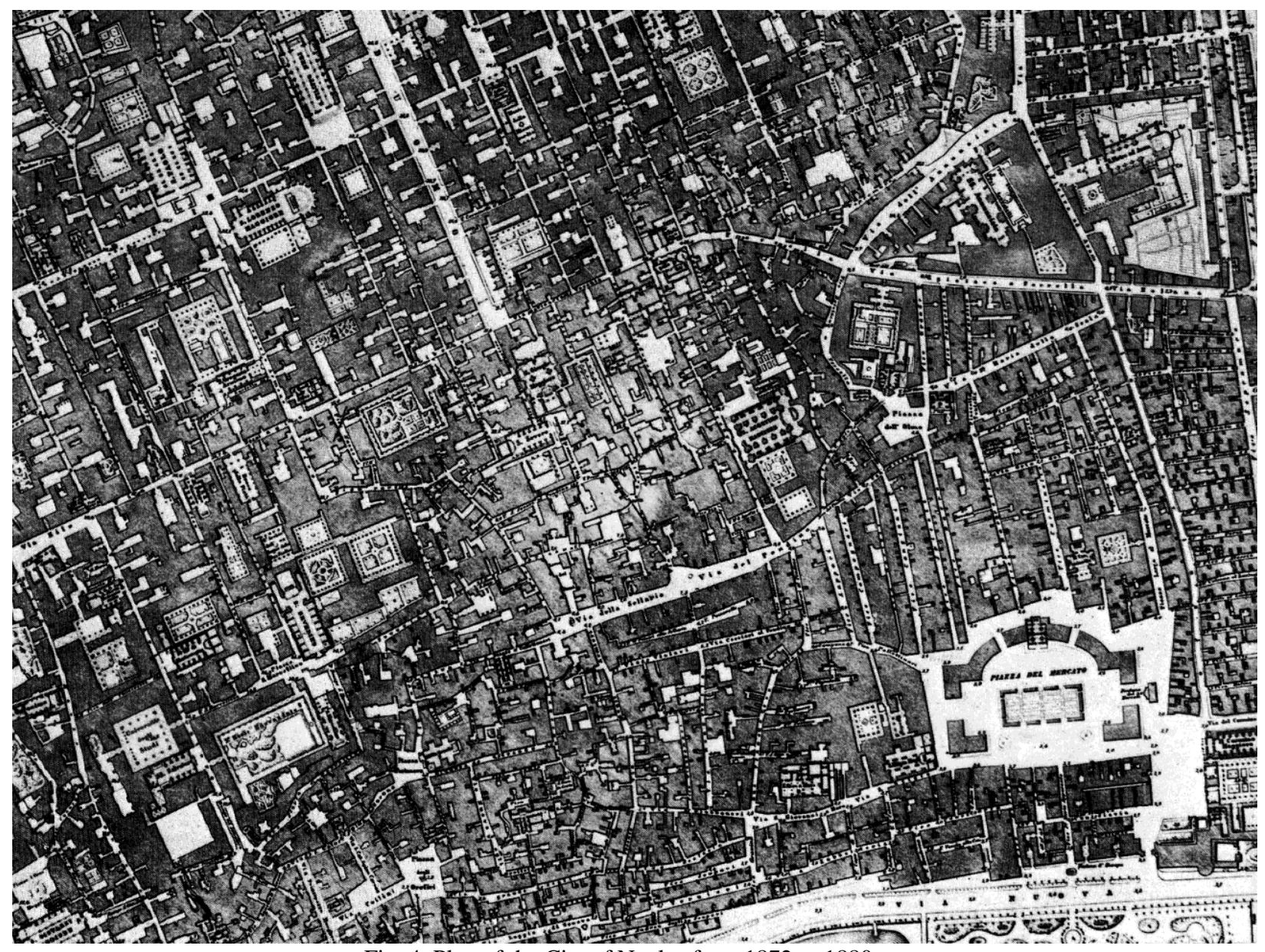

Fig. 4: Plan of the City of Naples from 1872 to 1880. 


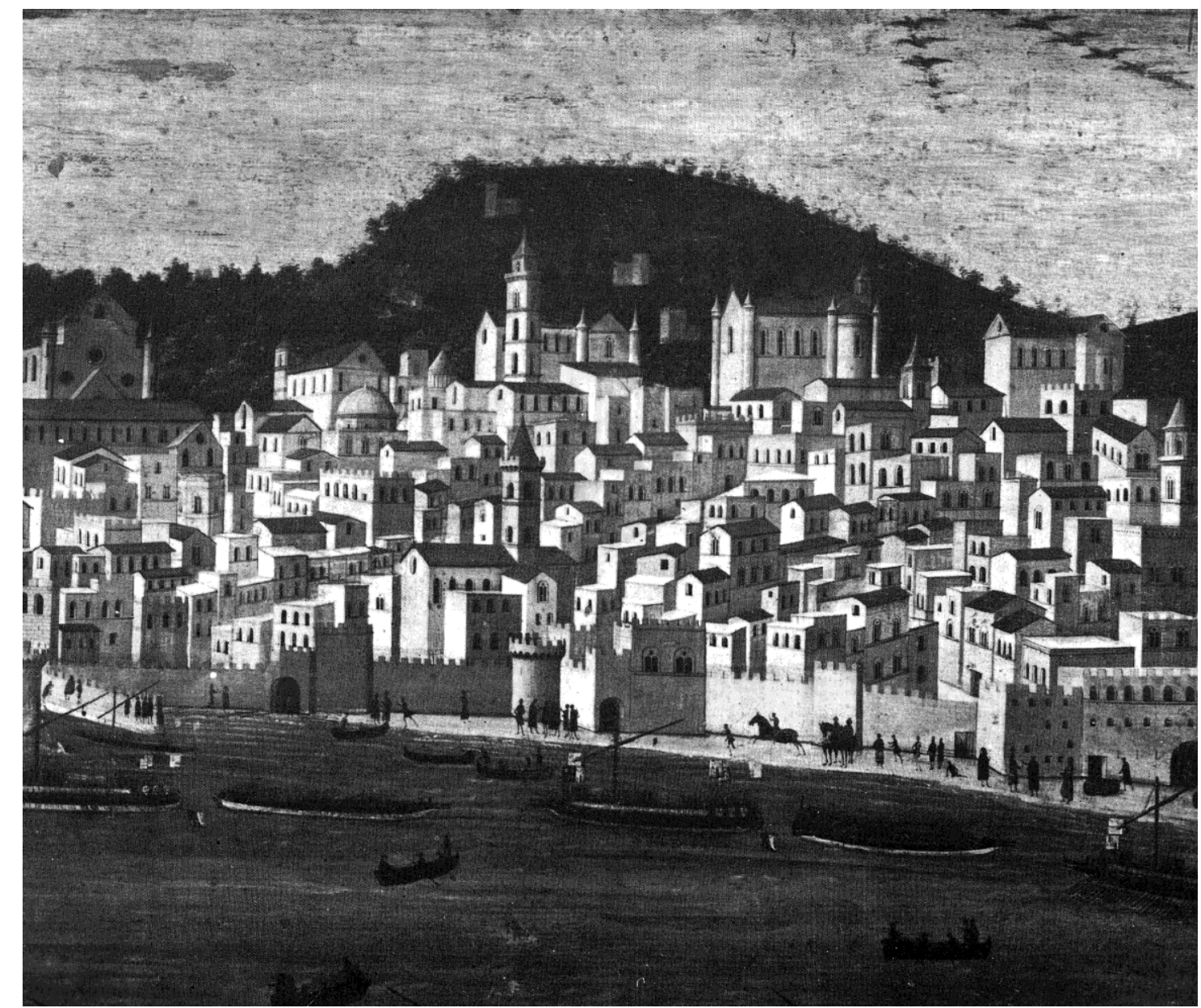

Fig. 5: Tavola Strozzi, 1464 (Naples, Museo di Capodimonte), detail.
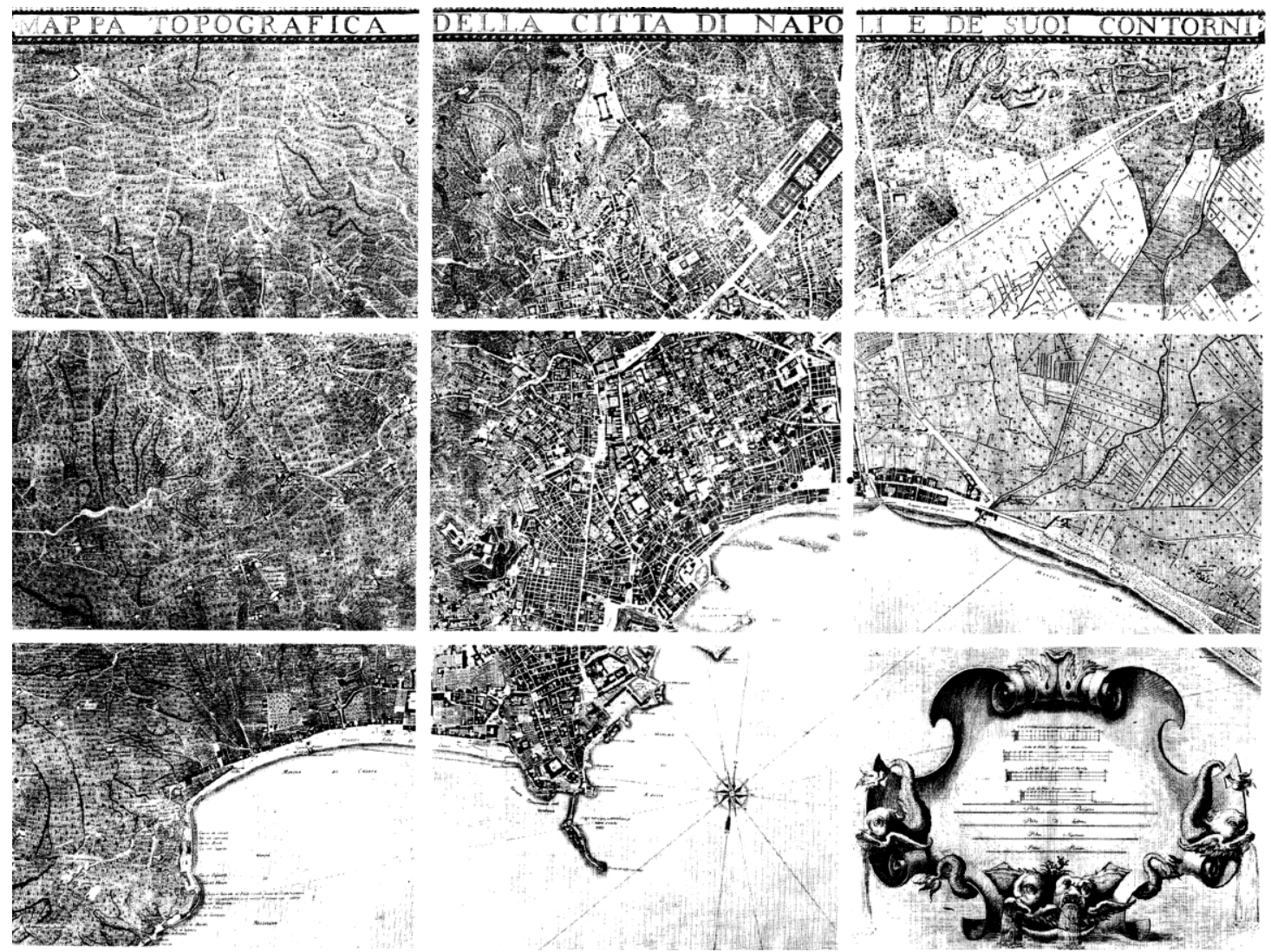

Fig. 6: The Angevin city: established or restructured churches 


\section{II.THE DRAWING OF THE RELIGIOUS STRUCTURES}

The Duomo takes up almost throughout the insula between Decumano greater. It is accessed passing the stately fourteenth century portal of Antonio Baboccio da Piperno (1407), enriched by the Madonna col Bambino by Tino Camaino. The architectural space appears defined by scanning the large pillars between the naves and, above, by the seventeenth century wooden coffered ceiling, carved and gilded, in which are embedded among others, the paintings of Fabrizio Santafede and Girolamo Imparato. In the religious factory open large windows that illuminate the paintings by Luca Giordano, along the walls of the nave. On entering the first bay, where there is the original Gothic architecture highlighted by the recent restoration, there is a Greek bath, with the Egyptian basalt, which is the baptismal font. Proceeding along the left of the side aisle, we enter the Basilica of Santa Restituta. It dates from the first half of the fourth century and is the only church that was built by Emperor Constantine in Naples.

The structure was the first Neapolitan cathedral, probably dedicated to the Savior, and took the name of Santa Restituta near. Originally the church had five naves, but at the time of the construction of the Angevin Cathedral, as well as be reduced in length, saw her become three naves. Although the extensive remodeling that Arcangelo Guglielmelli had to work (1689-92) even today it is possible to recognize, preserved in their original site, the marble columns and other architectural elements of the Roman temple from which the early their church, erecting, then, next to it the first Neapolitan Baptistery S. Giovanni in Fonte. Originally it was an isolated building, with the entrance on the west wall, as shown by the recent restoration work. Another particularly striking space of the Cathedral is the transept, where, perhaps, there was, in the fifth century, the Stefania Cathedral. The current structure dates back to the restoration of the apse of 1741-44, made from the Paolo Posi, with regard to the architecture, and the sculptor Pietro Bracci for decoration and Assumption statuary surrounded by masses of clouds and golden rays systems. The side stairs at the entrance to the presbytery lead to a three aisled the crypt contained within a rectangle of about twelve meters for nine and divided among them ten composite columns. In the side walls there are five niches on each side with altars. Recent renovations have revealed archaeological finds of great value, as they can help to identify more exactly the Greek and Roman structures of existing buildings and the primitive Christian worship in the area where you went to plant the Angevin cathedral. Currently the excavation area is walkable is below of the apse of Santa Restituta and the adjacent Archbishop's Palace is below the external spaces, between the Curia and the Cathedral. Note should also be among the finds: the Greek period elements, made up of several and extensive tracts of the wall of a temple and a pavement area; numerous remains of Roman times, including the wall of another temple that develops at the Greek; at higher altitudes, the recoveries of the early Christian period and the early Middle Ages; also, the stretches of pavement in St. Restituta, and then beyond, to the Curia, the pavement section, made with lava stones basal (probably, a road artifact of the fourth or fifth century, inside a religious island). They are also of great interest the various stretches of pavement found in the larger environment adjacent to the area; other mosaics are also visible, from the opposite side, towards the Curia manufactured. Among the religious structures, of considerable interest is the Church and Convent of San Lorenzo Maggiore. The facade of the Basilica, originally, was to be the Gothic style, perhaps with a large window in the center. The portal was readjusted, in 1733, by Ferdinando Sanfelice in Baroque style, without hesitation on the contrary both to the interior Gothic both forms of the nearby bell tower. The interior of the Church is a Latin cross, showing a single nave flanked by open chapels, a polygonal apse and ambulatory with radial chapels. The reservoir of the choir and set to a polygonal perimeter, in which the central spider, divided into seven nails, match as many side chapels, at the conclusion of the ambulatory, crossed by an equal number of cruises. This structure ends with a rectangular cross raised over the transept and time, therefore, with the body of the choir. Then, with the diffusion of the Christian religion, many pagan temples were not destroyed but reused for creating churches; so the temple of Castore and Polluce, built in the first century by Tiberius Julius Tarsus in the Neapolitan Forum, now reduced in ruins, in the seventh century it was used, in part, to create a first church dedicated to Saint Paul. The radical works in the church began in 1576, when it was rebuilt the main access staircase, and, between 1583 and 1591, they proceeded to a substantial transformation of the interior of the Basilica. Between 1773 and 1774 it was completely rebuilt front view: the ancient temple, in fact, were used two tall columns with architraves, the foundation of the other two, on the front and another on the right side. In the old Monastery one can see the cloister, surrounded by 22 ancient columns of granite. Through the majestic triumphal arch you access the transept, where the left are preserved the tombs of Durazzo, the bottom opens the chapel of St. Antonio, a Baroque work of Cosimo Fanzago, while the sacristy is a Renaissance environment. On the right of the church stands the Convent. From the portal you enter a hallway, from which it passes into the eighteenth century cloister on the left side open the mullioned windows and triple lancet windows of the church. From the cloister there is also access to the area of the recent archaeological excavations, where you can see, among other things, the mighty walls of the Roman Age, of a public building forming the substructure of the Basilica; the route of a Roman road lined with shops; traces of Greek structures to large square blocks of tufo and, finally, at a higher level, the remains of a public building of the Middle Ages, probably a Seat. 


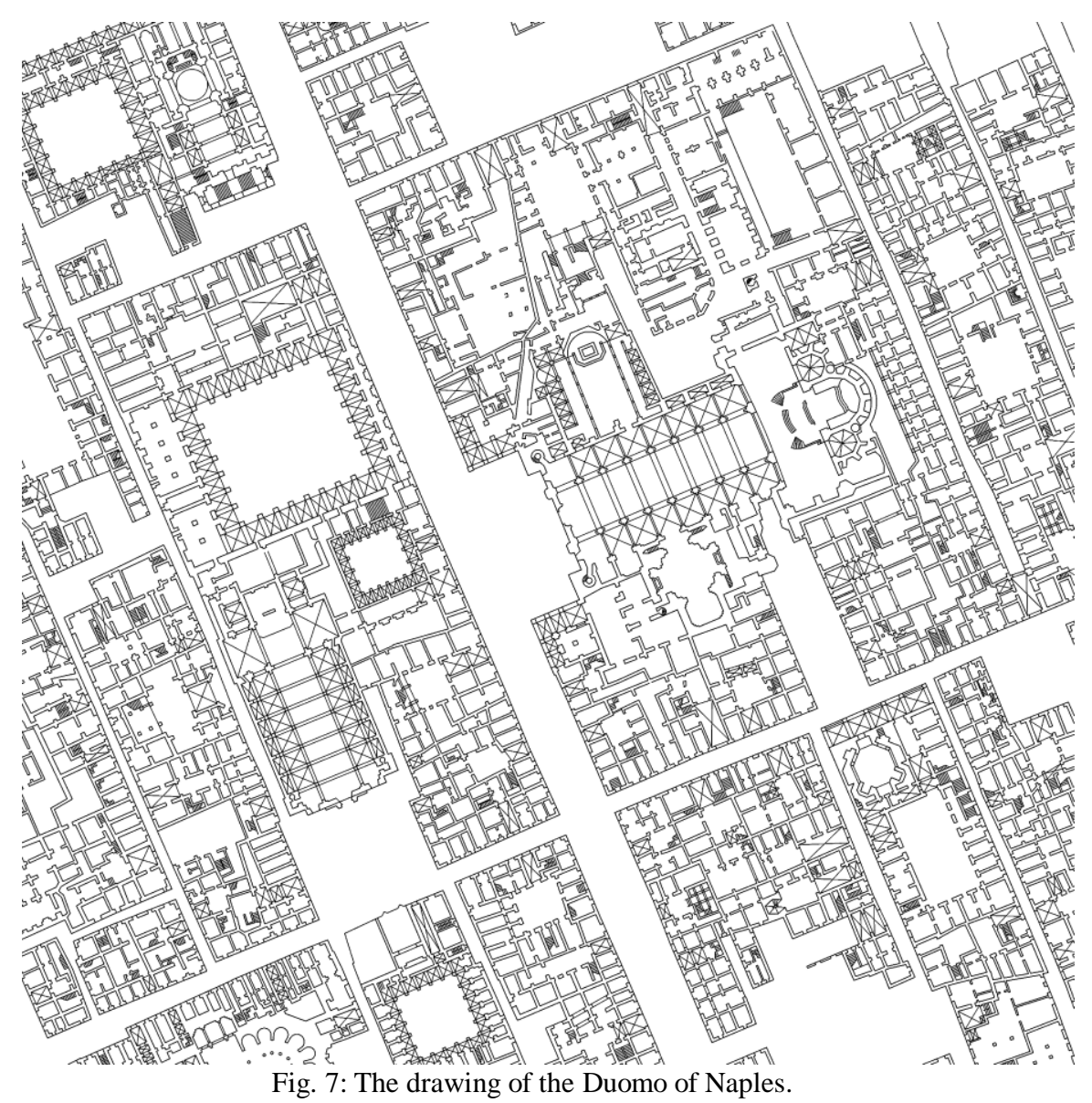

The Pio Monte della Misericordia, however, is one of the most important and ancient Neapolitan charities, born to the exercise of the Seven Works of the Misericordia Corporal, and even today, continuously it executes its activity. The institution, founded in 1602 , is based in the historic building, designed by the royal architect Francesco Antonio Picchiatti that preserves, inside, the elegant baroque church with a central plan, and with the main altar is a large painting by Caravaggio Seven Works of the Misericordia Corporal and in the following altars other masterpieces of painting and sculpture, such as the painting of Battistello Caracciolo the Liberation of San Pietro, which happens to be among the finest examples of the Neapolitan naturalism. On the first floor, the charming historic apartment rooms guard precious Quadreria with considerable collection of paintings and drawings by Francesco De Mura, artist of the eighteenth century Neapolitan and also works of famous Italian and foreign painters from the sixteenth to the nineteenth century. The Baroque Church, octagonal altar exposes the Caravaggio's masterpiece "The Seven Works of the Misericordia", which concentrates in a single large canvas as the Monte undertook to make since its founding. The palace, the church and the Picture Gallery create an inseparable unity and constitute a historical set of highly effective, allowing you to relive the atmosphere of this ancient charity, exposing one of the most interesting private collections open to the public, presented in a context of great charm which is the Piazza San Gaetano. Of great importance is the Piazza del Gesù and, in the middle of the stands, for about thirty meters, the white marble spire of the Immaculate, the decoration of which were engaged, from the beginning of the fourth decade of the eighteenth century, the architects Vaccaro, Bottiglieri and Pagano.
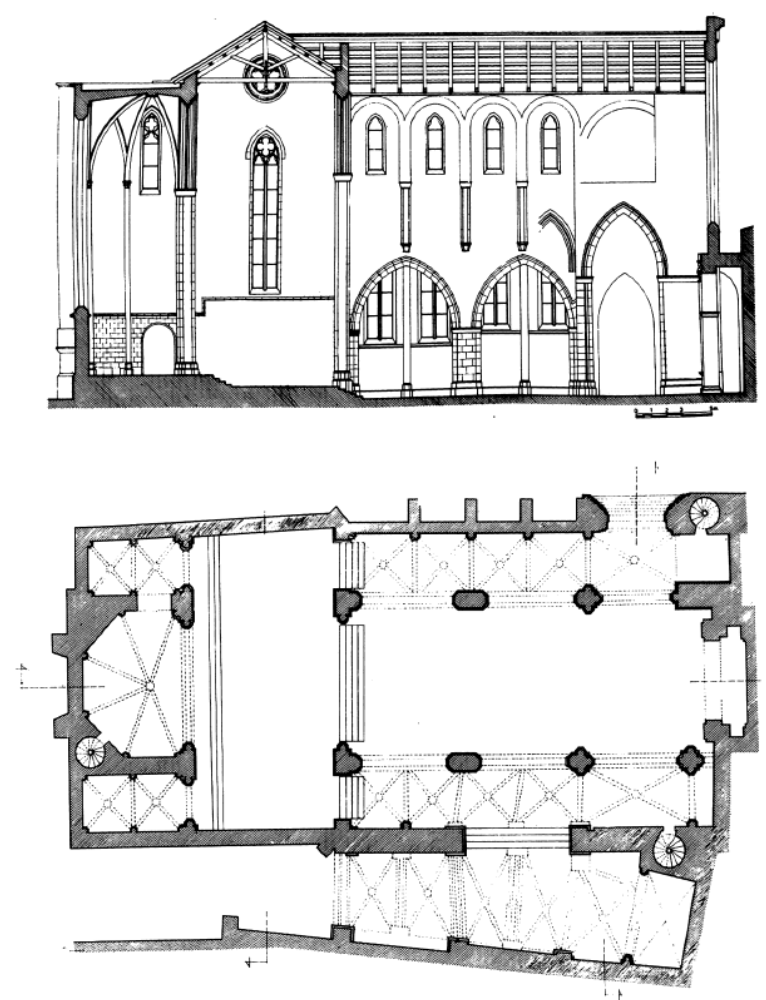

Fig. 8: The drawing of the San Domenico Maggiore

The Pio Monte della Misericordia, however, is one of the most important and ancient Neapolitan charities, born to the exercise of the Seven Works of the Misericordia Corporal, 
and even today, continuously it executes its activity. The institution, founded in 1602, is based in the historic building, designed by the royal architect Francesco Antonio Picchiatti that preserves, inside, the elegant baroque church with a central plan, and with the main altar is a large painting by Caravaggio Seven Works of the Misericordia Corporal and in the following altars other masterpieces of painting and sculpture, such as the painting of Battistello Caracciolo the Liberation of San Pietro, which happens to be among the finest examples of the Neapolitan naturalism. On the first floor, the charming historic apartment rooms guard precious Quadreria with considerable collection of paintings and drawings by Francesco De Mura, artist of the eighteenth century Neapolitan and also works of famous Italian and foreign painters from the sixteenth to the nineteenth century. The Baroque Church, octagonal altar exposes the Caravaggio's masterpiece "The Seven Works of the Misericordia", which concentrates in a single large canvas as the Monte undertook to make since its founding. The palace, the church and the Picture Gallery create an inseparable unity and constitute a historical set of highly effective, allowing you to relive the atmosphere of this ancient charity, exposing one of the most interesting private collections open to the public, presented in a context of great charm which is the Piazza San Gaetano. Of great importance is the Piazza del Gesù and, in the middle of the stands, for about thirty meters, the white marble spire of the Immaculate, the decoration of which were engaged, from the beginning of the fourth decade of the eighteenth century, the architects Vaccaro, Bottiglieri and Pagano.

The Piazza del Gesù also defined an urban area of considerable interest both because it gathers around its perimeter architectural episodes of exceptional value, from the fourteenth century church of Santa Chiara, the convent surrounding complex of the facade of the palace of Prince Sanseverino, behind which stands the Baroque church of the Gesù, the palace of Carata Pignatelli, the great portal. The last stretch, between the Piazza del Gesù and of St. Domenico Maggiore, is the one that presents the set of patricians the most valuable buildings. The Church of the Piazza del Gesù, is dominated by the great spire of the Immacolata, the seventeenth century work, which, with the other two, placed in Piazza San Domenico Maggiore and in the square Riaro Sforza, the outline of the lower Decumano development, which ended with the here Porta Reale, until, in the seventeenth century it was moved. After that date the Decumano will develop the reuse of existing structures of the palace of Roberto Sanseverino. The Church was built with a clever reuse of the fifteenth century building structures and, in particular, the facade with rusticated highlights of Iberian origin; in those particulars can admire the ancient marble portal of the main entrance to the Church, which still stand out on the arms of the Sanseverino family. It is, undoubtedly, one of the masterpieces of the Renaissance in Naples, both the proportions and the design for the refined execution; it is, however, later additions the two marble columns of composite order, the rampant truncated, statues and other sculptures. The church, therefore, was completed in 1600 and dedicated to the Immaculate. After a fire in 1639, they were carried out restoration work and landscaping under the direction of Cosimo Fanzago, who emphasized the Baroque character. In 1688, however, to a severe earthquake, the dome with admirably frescoed, was collapsed.

\section{REFERENCES}

[1] G. C. Alisio, Urbanistica napoletana del Settecento, Bari 1979.

[2] C. De Seta, Storia della città di Napoli dalle origini al Settecento, Bari 1973.

[3] L . Corniello, Il disegno multidimensionale della città di Ohrid in Macedonia. In: Disegno \& Città. A. Marotta, G. Novello, Roma: Gangemi Editore, 2015.

[4] L. Corniello, Knowledge in Apollonia. The medieval monastery and the territory. In: Heritage and Technology, Mind Knowledge Experience, C. Gambardella, Napoli: La scuola di Pitagora editrice, 2015.

[5] L . Corniello, The multidimensional approaches aimed at knowledge, conservation and regeneration of the Albanian territory. In: International Conference on Artificial Intelligence and Manufacturing Engineering (ICAIME'2014) \& International Conference on Architecture And Civil Engineering (ICAACE'14) \& 2014 International conference on Advanced Engineering Technologies (AET-2014). Dubai: URCAE, 2014.

[6] P. Giordano, L . Corniello, Atlante Grafico e Teorico Amalfitano. La conoscenza e la modificazione del paesaggio costiero. Napoli: La scuola di Pitagora editrice, 2014

[7] A. Gambardella, Ferdinando Sanfelice Architetto, Napoli 1974

[8] C. Gambardella, Atlante di Pompei, Napoli: La scuola di Pitagora editrice, 2012.

[9] P. Giordano, Il disegno dell'architettura costiera. Napoli: La scuola di Pitagora editrice, 2012.

[10] P. Giordano, Ferdinando Fuga a Napoli. L'Albergo dei Poveri, il Cimitero delle 366 Fosse, i Granili, Lecce: Edizioni del Grifo, 1997.

[11] P. Giordano, L'Albergo dei Poveri a Napoli, Napoli: La scuola di Pitagora editrice, 2014

[12] R. Pane, Napoli imprevista, Torino 1949.

[13] A. Venditti, Architettura neoclassica a Napoli, Napoli 1961. 